\title{
Penggunaan Metode Pembelajaran Team Quiz sebagai Upaya Meningkatkan Prestasi Belajar IPA
}

\author{
I Gusti Agung Sri Parnayathi* \\ SMP Negeri 3 Banjarangkan, Klungkung, Indonesia
}

A R T I C L E I N F O

Article history:

Received 19 August 2020

Received in revised form

30 September 2020

Accepted 10 October 2020

Available online 29

November 2020

\section{Kata Kunci:}

Prestasi Belajar, Metode

Pembelajaran Team Quiz

Keywords:

Learning Achievement,

Team Quiz Learning

Method

\begin{abstract}
A B S T R A K
Kemampuan siswanya untuk kompetensi mata pelajaran IPA cukup rendah. Tujuan penulisan penelitian tindakan kelas ini adalah untuk mengetahui apakah penggunaan Metode Pembelajaran Team Quiz dalam pembelajaran IPA dapat meningkatkan prestasi belajar siswa kelas VIII A. Metode pengumpulan datanya adalah tes prestasi belajar. Metode analisis datanya adalah deskriptif. Hasil yang diperoleh dari penelitian Penggunaan Metode Pembelajaran Team Quiz dalam pembelajaran IPA dapat meningkatkan prestasi belajar siswa kelas VIII A. Ini terbukti dari hasil yang diperoleh pada yang awalnya 65,65 setelah diberikan tindakan pada siklus I meningkat menjadi 69,73 dan pada siklus II meningkat lagi menjadi 78,42. Kesimpulan yang diperoleh dari penelitian ini adalah Penggunaan Metode Pembelajaran Team Quiz.
\end{abstract}

\section{A B S T R A C T}

This research was carried out in Banjarangkan Middle School 3 in class VIII. A student's ability for science subject competencies was quite low. The purpose of learning this class research is to learn whether using the Quiz Team Learning Method in natural science learning can improve student achievement in class VIII A. The data collection method is a learning achievement test. The data analysis method is descriptive. The results obtained from the study using the Quiz Learning Method in natural science learning can improve student achievement in class VIII $A$. This is evident from the results obtained at 65.65 after taking action in the first cycle increased to 69.73 and in the second cycle increased again to 78.42. The conclusion obtained from this study is that the use of the Quiz Team Learning Method in science learning can improve the learning achievement of students of class VIII A in SMP Negeri 3 Banjarangkan.

\section{Pendahuluan}

Pendidikan di Indonesia memiliki tujuan untuk mengembangkan manusia menjadi manusia yang utuh. Mengembangkan siswa menjadi manusia yang utuh tentu bukan hanya meningkatkan kemampuan pada tingkat kognitif, melainkan juga afektif dan psikomotorik (Marcella, 2018). Menurut (Munirah, 2015) sistem pendidikan di Indonesia dewasa ini tampak ada kesenjangan antara kenginan dan realita. Secara makro dapat dilihat dalam aspek pengelolaan, peran pemerintah dan masyarakat, kurikulum atau materi ajar, pendekatan dan metodologi pembelajaran, sumber daya manusia, lingkungan kampus atau sekolah, dana, dan akreditasi. Kesenjangan dalam sistem pendidikan tersebut disebabkan karena faktor politik, ekonomi, sosial-budaya dan sebagainya yang selalu berubah sesuai dengan perubahan dan perkembangan zaman. IPA merupakan mata pelajaran yang sering dianggap sulit oleh para siswa. Para pendidik muncul masalah bagaimana cara menyampaikan ilmu pengetahuan tersebut kepada para siswa sehingga siswa dapat mengerti tentang ilmu pengetahuan yang telah diajarkan dan perkembangannya, baik mengenai pengertian-pengertian pokok maupun persoalan yang kompleks. Proses pembelajaran IPA SMP membuat 
kondisi siswa berhadapan dengan teori-teori dan soal-soal yang kadang-kadang menjemukan, karena materi pelajaran yang dihadapi siswa bersifat abstrak. Selain itu IPA bukan merupakan pelajaran hafalan sehingga diperlukan praktikum. Semua uraian di atas menunjukkan hal-hal yang perlu dalam upaya meningkatkan prestasi belajar siswa seperti penguasaan metode-metode ajar, penguasaan model-model pembelajaran; penguasaan teori-teori belajar penguasaan teknik-teknik tertentu; penguasaan peran fungsi serta kegunaan mata pelajaran. Apabila betul-betul guru menguasai dan mengerti tentang hal-hal tersebut dapat diyakini bahwa prestasi belajar peserta didik pada mata pelajaran IPA tidak akan rendah. Namun kenyataannya prestasi belajar siswa Kelas VIII A di Semester II Tahun Pelajaran 2017/2018 baru mencapai nilai rata-rata 66,52 masih di bawah nilai rata-rata KKM (75). Kesenjangan antara harapanharapan yang telah disampaikandengan kenyataan lapangan dalam upaya memperbaikimutu pendidikan utamanya pada mata pelajaran IPA, sangat perludilakukan perbaikan cara pembelajaran. Agar para siswa dapat tertarik dengan IPA, maka pada proses pembelajaran tidak hanya ceramah tetapi perlu dilakukan kegiatan laboratorium yang berupa eksperimen, praktikum, demonstrasi, peragaan alat peraga, peragaan slide proyektor, diskusi dan lain-lain yang melibatkan laboratorium beserta alat dan bahannya. IPA merupakan ilmu pengetahuan yang mempunyai kekhususan, letak kekhususannya adalah pada metode yang digunakan oleh para ilmuwan untuk memperoleh pengetahuan tersebut.

Metode IPA, yaitu suatu proses atau kegiatan ilmiah yang mempunyai langkah-langkah dan tata cara khas yakni observasi dan eksperimen. Oleh karena itu mengajarkan IPA tidak hanya memberikan informasi ilmiah kepada siswa, melainkan juga melatih siswa bekerja seperti para ilmuwan 1 bekerja. Dengan kata lain siswa harus menghayati metode IPA dan mempraktekkan sewaktu belajar IPA. IPA dapat dipandang sebagai suatu proses dari upaya manusia untuk memahami gejala alam, dipandang sebagai suatu produk dari upaya manusia untuk memahami alam, dan IPA dapat dipandang sebagai faktor yang dapat mengubah sikap dan pandangan manusia terhadap alam semesta dari sudut pandang metalogis menjadi sudut pandang ilmiah. Sesuai dengan hakekat dari IPA, maka tujuan pendidikan tidaklah hanya sekedar agar siswa dapat memiliki pengetahuan tentang gejala-gejala alam saja, melainkan melalui pendidikan IPA diharapkan pada siswa terbentuk kemampuan memecahkan masalah-masalah mengenai alam sekitarnya sesuai dengan cara serta sikap yang dikehendaki dalam IPA. Memperhatikan tujuan dan esensi pendidikan IPA, sudah selayaknya guru mampu mempersiapkan, membina, dan membentuk kemampuan peserta didik yang menguasai pengetahuan, sikap, nilai, dan kecakapan dasar yang diperlukan bagi kehidupan di masyarakat. Untuk menunjang tercapainya tujuan IPA tersebut harus didukung oleh iklim pembelajaran yang kondusif. Iklim pembelajaran yang dikembangkan oleh guru mempunyai pengaruh yang sangat besar terhadap keberhasilan dan kegairahan belajar siswa. Kualitas dan keberhasilan pembelajaran sangat dipengaruhi oleh kemampuan dan ketetapatan guru memilih dan menggunakan metode pembelajaran (Sulistyorini, 2007).

Pemilihan model dan metode pembelajaran yang sesuai dengan tujuan kurikulum dan potensi siswa merupakan kemampuan dan keterampilan dasar 2 yang harus dimiliki oleh seorang guru. Hal ini didasari oleh asumsi bahwa ketepatan guru dalam memilih model dan metode pembelajaran akan berpengaruh terhadap keberhasilan dan Prestasi Belajar siswa, karena model dan metode pembelajaran yang digunakan oleh guru berpengaruh terhadap kualitas proses belajar yang dilakukannya. Berbagai model pembelajaran Ilmu Pengetahuan Alam (IPA) masih banyak menggunakan metode pembelajaran konvensional, seperti metode ceramah, diskusi, tanya jawab, pemberian tugas, sosio drama, dan sebagainya. Penggunaan metode-metode tersebut masih sering berdiri sendiri, dan ternyata hasilnya masih kurang memuaskan.

Menurut (Hermanto, 2018) Team Quiz merupakan metode dimana siswa dilatih untuk belajar dan berdiskusi kelompok. Satu kelompok presentasi ke kelompok lain, kemudin memberikan kuis ke kelompok lain tersebut. Apabila kelompok tersebut tidak bisa menjawab maka pertanyaan dilempar ke kelompok selanjutnya, dan seterusnya hingga semua kelompok melakukan presentasi kemudian memberikan kuis. Dapat juga dilakukan dengan cara guru memberikan quiz, soal, atau permasalahan rebutan untuk di jawab masing-masing kelompok untuk rebutan mendapatkan point terbanyak. Menurut (Dalvi, 2006) bahwa Team Quiz "merupakan salah satu tipe pembelajaran yang mampu meningkatkan keaktifan siswa dalam proses belajar". Jadi, model pembelajaran Team Quiz adalah model pembelajaran yang mampu meningkatkan keaktifan dan tanggung jawab siswa melalui melalui kegiatan bertanya dan menjawab dalam suasana yang menyenangkan. Menurut (Srijayanti, 2014) Dalam proses belajar mengajar dengan menggunakan model pembelajaran Team Quiz ini, siswa bersama-sama dengan timnya mempelajari materi dalam lembaran kerja, mendiskusikan materi, saling memberikan arahan, saling memberi pertanyaan dan jawaban. Materi belajar dibagi sesuai dengan jumlah tim sehingga masingmasing tim akan memperoleh kesempatan sebagai tim penanya dan tim penjawab. Dalam penelitian (Darwanti, 2017), dapat dijelaskan alasan dipilihnya metode pembelajaran quiz team dikarenakan dengan adanya kompetisi antar kelompok yang dirancang dalam suatu permainan yang 
menjadikan siswa aktif mencari penyelesaian masalah yang menjadi tanggung jawabnya dalam kegiatan kuis, pembelajaran tidak membosankan, dan mengkomunikasikan pengetahuan yang dimilikinya kepada orang lain, sehingga masing-masing siswa diharapkan lebih memahami konsep, menguasai materi dan dapat memecahkan permasalahan yang bervariasi. Penelitian yang dilakukan oleh (Fadilah, 2019) yang menyatakan bahwa penelitian tindakan di kelas XI IPS 2 SMAN 8 Kediri pada pelajaran Ekonomi materi pendapatan nasional dengan menerapkan model pembelajaran Quiz Team dapat meningkatkan hasil belajar peserta didik. Kemudian penelitian yang dilakukan (Sabil \& Winarni, 2013) menyatakan bahwa tipe quiz team dalam pembelajaran matematika mampu meningkatkan hasil belajar matematika siswa.

Hasil penelitian ini sejalan dengan hasil penelitian yang dilakukan oleh (Saputra et al., 2017) dengan judul Pengaruh Model Pembelajaran Quiz Team Berbasis Permainan Kamus Mini terhadap Hasil Belajar IPS Siswa Kelas V SD Gugus IV Abiansemal Tahun Pelajaran 2016/2017. Hasil analisis data diperoleh thitung $=5,32>$ ttabel $=2,00$ untuk signifikan $5 \%$ dan $\mathrm{dk}=61$. Berdasarkan kriteria pengujian, maka H_o ditolak dan H_a diterima. Adapun nilai rata-rata hasil belajar pengtahuan IPS yang dibelajarkan dengan model pembelajaran quiz team berbasis permainan kamus mini 78,25 dan siswa yang dibelajarkan dengan pembelajaran konvensional 69,58. Berdasarkan hasil penelitian tersebut dapat disimpulkan bahwa terdapat pengaruh model pembelajaran quiz team berbasis permainan kamus mini terhadap hasil belajar pengetahuan IPS siswa kelas V SD Gugus IV Kecamatan Abiansemal Tahun Pelajaran 2016/2017. Selanjutnya hasil penelitian yang dilakukan oleh (Srijayanti et al., 2014) dengan judul Model Pembelajaran Team Quiz Berbantuan Media Gambar Berpengaruh Terhadap Hasil Belajar IPS Siswa Kelas V. Berdasarkan hasil analisis uji-t diperoleh thitung > ttabel $(4.02>2.000)$, maka Ho ditolak dan Ha diterima. Hasil penelitian menunjukkan bahwa rata-rata hasil belajar IPS siswa yang dibelajarkan dengan model pembelajaran Team Quiz berbantuan media gambar lebih tinggi daripada rata-rata hasil belajar IPS yang dibelajarkan dengan pembelajaran konvensional $(80,53>68,13)$. Dengan demikian dapat disimpulkan bahwa model pembelajaran Team Quiz berbantuan media gambar berpengaruh terhadap hasil belajar IPS siswa kelas V SD Gugus IV Kecamatan Kuta Utara tahun ajaran 2013/2014.

Berdasarkan jabaran tersebut maka dirumuskan sebuah penelitian tindakan yang mana, penelitian tindakan ini mempunyai Tujuan penulisan penelitian tindakan kelas ini adalah untuk mengetahui apakah penggunaan Metode Pembelajaran Team Quiz dalam pembelajaran IPA dapat meningkatkan prestasi belajar siswa kelas VIII A.

\section{Metode}

Dalam melaksanakan Penelitian Tindakan Kelas, langkah-langkah atau prosedur PTK didasarkan pada model rancangan PTK dari para ahli. Selama ini dikenal berbagai model PTK, namun pada dasarnya terdapat empat tahap yang harus dilalui yaitu (1) perencanan (planning), (2) pelaksanaan (acting), (3) pengamatan (observing), dan (4) refleksi (reflecting). Keempat tahap tersebut merupakan satu siklus dan akan dapat berlanjut kepada siklus kedua, siklus ketiga dan seterusnya sesuai dengan apa yang diinginkan dalam penelitian.

Untuk penelitian ini penulis memilih rancangan penelitian tindakan yang disampaikan Mc. Kernan seperti terlihat pada gambar berikut: 


\section{Mc. Kernan}

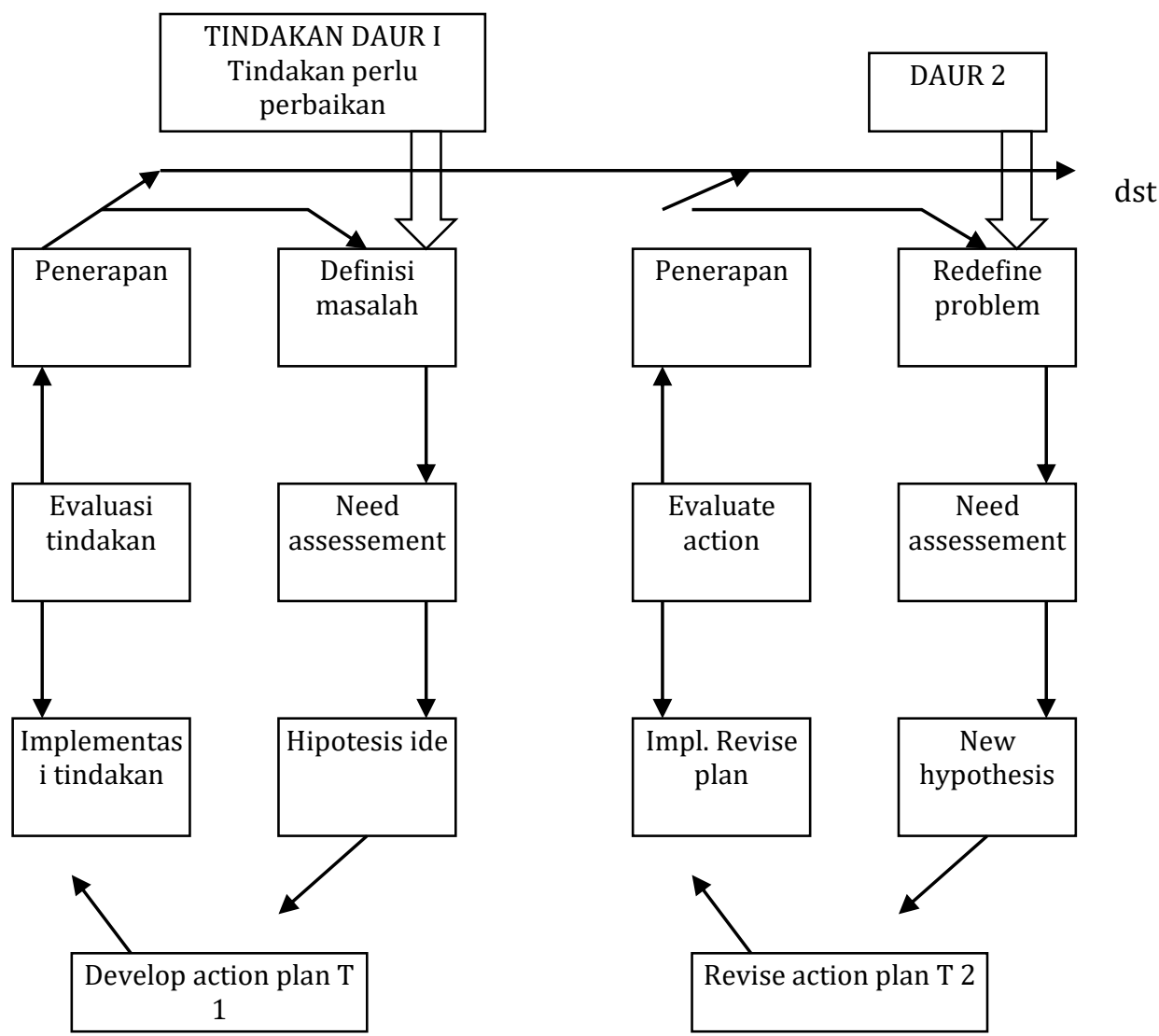

Gambar 1. Penelitian Tindakan Model Mc. Kernan, 1991

(dalam (Sukidin et al., 2002)

Prosedur: 1) Tindakan daur I: mulai dari definisi masalah, berlanjut ke assessment yang disiapkan, berlanjut ke rumusan hipotesis, berlanjut ke pengembangan untuk tindakan I, lalu implementasi tindakan, evaluasi tindakan berlanjut ke penerapan selanjutnya. 2) Tindakan daur II: mulai dari menentukan kembali masalah yang ada, berlanjut ke assessment yang disiapkan, terus ke pemikiran terhadap munculnya hipotesis yang baru, perbaikan tindakan pada rencana ke 2, pelaksanaan tindakan, evaluasi terhadap semua pelaksanaan dan penerapan. Prosedur yang dilakukan dengan model ini adalah pada awalnya menemukan kekurangan-kekurangan yang ada, setelah dianalisis ternyata kemampuan anak dalam pelajaran IPA masih rendah sehingga dibuat perencanaan, dilanjutkan dengan langkah-langkah tindakan yaitu melatih terus sesuai kaidah pembelajaran di SMP karena penilaian terhadap kemajuan anak harus diupayakan berkesinambungan, begitu juga penilaiannya. (Fridani et al., 2009) mengatakan bahwa assesment perkembangan anak dilaksanakan secara terus menerus dan berkesinambungan. Setelah langkah tindakan dimonitor berserta efeknya serta kegagalannya bisa ditemukan, dibuat revisi untuk perencanaan selanjutnya. Demikian terus bergulir sampai penelitian berhasil sesuai indikator yang diusulkan. Untuk indikator tersebut ada di Bab III ini dibagian yang paling akhir.

Pengumpulan data dalam penelitian ini menggunakan tes prestasi belajar. Tes prestasi belajar berupa tes soal isian maupaun esay. Untuk menganalisis data hasil penelitian ini digunakan metode deskriptif. Untuk data kuantitatif dianalisis dengan mencari mean, median, modus, membuat interval kelas dan melakukan penyajian dalam bentuk tabel dan grafik. Indikator keberhasilan penelitian yang diusulkan dalam penelitian ini pada siklus I dan II mencapai nilai rata-rata 75,00 dengan ketuntasan belajar 85\%. dengan KKM yang ditetapkan untuk mata pelarajan IPA pada SMP Negeri 3 Banjarangkan adalah 75.

\section{Hasil dan Pembahasan}

Berdasarkan hasil penelitian yang diperoleh dari kegiatan awal menunjukkan bahwa: data pada awal pembelajaran diperoleh nilai rata-rata 66,52 siswa yang tuntas hanya $9(39,13 \%)$ dan yang tidak tuntas tuntas ada 14 orang $(60,86 \%)$ hal ini masih jauh dari harapan tujuan pembelajaran yang ingin 
dicapai adalah 85\%. Hasil pada awal pembelajaran ini masih sangat jauh dari harapan hal ini terjadi karena guru belum menggunakan model pembelajaran dan RPP masih bersifat konvensional. Untuk meninggkatkan Prestasi Belajar siswa kelas VIII A semester II SMP Negeri 3 Banjarangkan tahun pelajaran 2017/2018 sangat perlu ditingkatkan dengan melakukan perbaikan pembelajaran pada siklus I dengan menggunakan Metode Pembelajaran Team Quiz.

Hasil penelitian pada siklus I menunjukkan bahwa hasil yang diperoleh belum mencapai target dari indikator keberhasilan penelitian. Hal ini disebabkan oleh masih belum sempurnanya rancangan pembelajaran yang akan disampaikan guru. Namun pada siklus I sudah menunjukan peningkatan minat siswa dalam mengikuti pembelajaran yaitu dari data awal yang hanya mncapai rata-rata 66,52 meningkat menjadi 73,47 . Sedangkan presentase ketuntasan meningkat dari $39,13 \%$ pada data awal menjadi $73,91 \%$ pada siklus I.

Dengan tindakan yang sangat maksimal dan pelaksanaan yang betul-betul mengikuti kebenaran teori sesuai dengan Metode Pembelajaran Team Quiz dalam pembelajaran IPA di kelas VIII A SMP Negeri 3 Banjarangkan, hasil yang diperoleh pada siklus II ini ternyata Prestasi Belajar IPA meningkat secara signifikan dengan nilai rata-rata 80,86, dan ketuntasan belajarnya adalah 95,65\%.

Semua hasil yang diperoleh dari awal, siklus I dan siklus II digambarkan sebagai berikut.

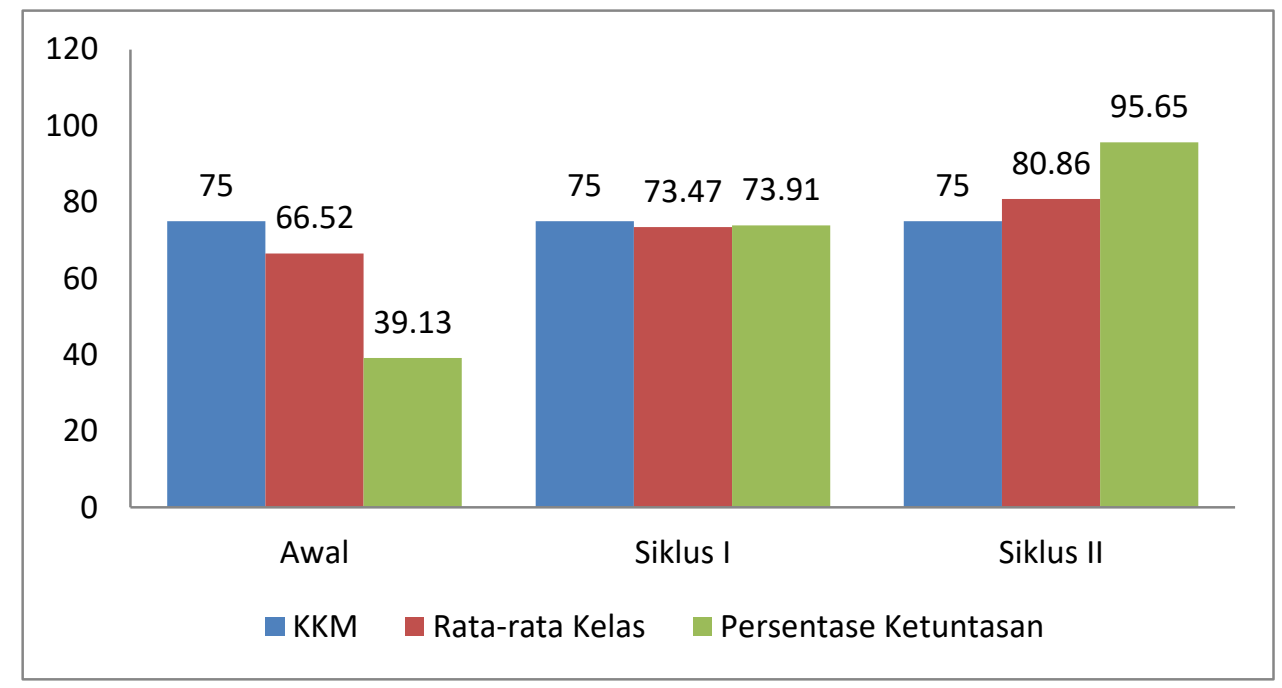

Gambar 2. Histogram Prestasi Belajar IPA Siswa Kelas VIII A SMP Negeri 3 Banjarangkan

Berdasarkan grafik tersebut nampak bahwa terjadi engkatan hasil belajar pada prasiklus, Siklus I dan siklus II. Hal ini tidak bisa terlepas dari proses pembelajaran yang dilakukan, dimana dengan adanya metode Team Quiz dimana dengan adanya Langkah-langkah sistematis siswa akan lebih terstruktur belajarnya. Metode Team Quiz diawali dengan guru menerangkan materi secara klasikal, lalu siswa dibagi ke dalam kelompok-kelompok besar. Semua anggota kelompok bersama-sama mempelajari materi tersebut, saling memberi arahan, saling memberikan pertanyaan dan jawaban untuk memahami materi tersebut. Setelah selesai materi maka diadakan suatu pertandingan akademis. Dengan adanya pertandingan akademis ini maka terciptalah kompetisi antara kelompok, para siswa akan senantiasa berusaha belajar dengan motivasi yang tinggi agar dapat memperoleh nilai yang tinggi dalam pertandingan. Teknik ini meningkatkan kemampuan tanggung jawab peserta didik terhadap apa yang mereka pelajari melalui cara yang menyenangkan dan tidak menakutkan. Penelitian yang dilakukan oleh (Marcella et al., 2018) menyatakan bahwa penerapan Team Quiz dapat meningkatkan kemampuan kerja sama antar siswa kelas VIII-B pada mata pelajaran Matematika. Kemudian penelitian yang dilakukan oleh (Fadilah, 2019) yang menyatakan bahwa penelitian tindakan di kelas XI IPS 2 SMAN 8 Kediri pada pelajaran Ekonomi materi pendapatan nasional dengan menerapkan model pembelajaran Quiz Team dapat meningkatkan hasil belajar peserta didik. Kemudian penelitian yang dilakukan (Sabil \& Winarni, 2013) menyatakan bahwa tipe quiz team dalam pembelajaran matematika mampu meningkatkan hasil belajar matematika siswa.

Metode team Quiz mengambangkan kemapuan sosial dan kerja sama siswa, dengan adanya interasksi dan kerja sama siswa aakan membantu siswa belajara lebih nayaman. Menurut (Hermanto, 2018) Team Quiz merupakan metode dimana siswa dilatih untuk belajar dan berdiskusi kelompok. Satu kelompok presentasi ke kelompok lain, kemudin memberikan kuis ke kelompok lain tersebut. Apabila 
kelompok tersebut tidak bisa menjawab maka pertanyaan dilempar ke kelompok selanjutnya, dan seterusnya hingga semua kelompok melakukan presentasi kemudian memberikan kuis. Dapat juga dilakukan dengan cara guru memberikan quiz, soal, atau permasalahan rebutan untuk di jawab masingmasing kelompok untuk rebutan mendapatkan point terbanyak. Menurut (Dalvi, 2006) bahwa Team Quiz "merupakan salah satu tipe pembelajaran yang mampu meningkatkan keaktifan siswa dalam proses belajar". Jadi, model pembelajaran Team Quiz adalah model pembelajaran yang mampu meningkatkan keaktifan dan tanggung jawab siswa melalui melalui kegiatan bertanya dan menjawab dalam suasana yang menyenangkan. Menurut (Srijayanti, 2014) Dalam proses belajar mengajar dengan menggunakan model pembelajaran Team Quiz ini, siswa bersama-sama dengan timnya mempelajari materi dalam lembaran kerja, mendiskusikan materi, saling memberikan arahan, saling memberi pertanyaan dan jawaban. Materi belajar dibagi sesuai dengan jumlah tim sehingga masingmasing tim akan memperoleh kesempatan sebagai tim penanya dan tim penjawab.

Setiap strategi berupa model dan metode pembelajaran memiliki kelebihan dan kelemahan masingmasing. Menurut Trisuparni (Karno, 2014) ada beberapa kelebihan dan kelemahan dalam metode Team Quiz. Kelebihannya antara lain adalah dapat menghilangkan kebosanan dalam lingkungan belajar, membangun kreatifitas diri siswa, meraih makna belajar melalui pengalaman karena memfokuskan siswa sebagai subjek belajar, menambah semangat dan minat belajar siswa, memberdayakan semua potensi dan indera peserta didik, menggunakan metode dan media yang bervariasi, serta disesuaikan dengan pengetahuan yang sudah ada. Adapun kelemahan metode ini, antara lain adalah peserta didik sulit mengorientasikan pemikirannya ketika tidak didampingi oleh pendidik, pembahasan terkesan ke segala arah atau tidak terfokus, memerlukan kendali yang ketat dalam mengkondisikan kelas saat keributan terjadi, hanya siswa tertentu yang dianggap pintar dalam kelompok tersebut, yakni yang bisa menjawab soal kuis karena permainan yang dituntut cepat dan memberikan kesempatan diskusi yang singkat, serta memerlukan waktu yang lama.

Hasil penelitian ini sejalan dengan hasil penelitian yang dilakukan oleh (Saputra et al., 2017) dengan judul Pengaruh Model Pembelajaran Quiz Team Berbasis Permainan Kamus Mini terhadap Hasil Belajar IPS Siswa Kelas V SD Gugus IV Abiansemal Tahun Pelajaran 2016/2017. Hasil analisis data diperoleh thitung $=5,32>$ ttabel $=2,00$ untuk signifikan $5 \% \mathrm{dan} \mathrm{dk}=61$. Berdasarkan kriteria pengujian, maka H_o ditolak dan H_a diterima. Adapun nilai rata-rata hasil belajar pengtahuan IPS yang dibelajarkan dengan model pembelajaran quiz team berbasis permainan kamus mini 78,25 dan siswa yang dibelajarkan dengan pembelajaran konvensional 69,58. Berdasarkan hasil penelitian tersebut dapat disimpulkan bahwa terdapat pengaruh model pembelajaran quiz team berbasis permainan kamus mini terhadap hasil belajar pengetahuan IPS siswa kelas V SD Gugus IV Kecamatan Abiansemal Tahun Pelajaran 2016/2017. Selanjutnya hasil penelitian yang dilakukan oleh (Srijayanti et al., 2014), dengan judul Model Pembelajaran Team Quiz Berbantuan Media Gambar Berpengaruh Terhadap Hasil Belajar IPS Siswa Kelas V. Berdasarkan hasil analisis uji-t diperoleh thitung > ttabel $(4.02>2.000)$, maka Ho ditolak dan Ha diterima. Hasil penelitian menunjukkan bahwa rata-rata hasil belajar IPS siswa yang dibelajarkan dengan model pembelajaran Team Quiz berbantuan media gambar lebih tinggi daripada rata-rata hasil belajar IPS yang dibelajarkan dengan pembelajaran konvensional $(80,53>68,13)$. Dengan demikian dapat disimpulkan bahwa model pembelajaran Team Quiz berbantuan media gambar berpengaruh terhadap hasil belajar IPS siswa kelas V SD Gugus IV Kecamatan Kuta Utara tahun ajaran 2013/2014.

\section{Simpulan dan Saran}

Berdasarkan penelitian yang telah dilakukan, dapat disimpulkan bahwa: Penggunaan Metode Pembelajaran Team Quiz secara efektif dapat Meningkatkan Prestasi Belajar IPA Pada Siswa Kelas VIII A SMP Negeri 3 Banjarangkan Semester II Tahun Pelajaran 2017/2018. Merujuk pada simpulan yang telah disampaikan di atas, dapat disarankan beberapa hal yakni dalam melaksanakan proses pembelajaran pada mata pelajaran IPA, penggunaan metode pembelajaran Team Quiz semestinya menjadi pilihan dari beberapa metode yang ada mengingat metode ini telah terbukti dapat meningkatkan kerjasama, berkreasi, bertindak aktif, bertukar informasi, mengeluarkan pendapat, bertanya, berdiskusi, berargumentasi dan lain-lain; walaupun penelitian ini sudah dapat membuktikan efek utama dari Metode Pembelajaran Team Quiz dalam meningkatkan aktivitas dan prestasi belajar, sudah pasti dalam penelitian ini masih ada hal-hal yang belum sempurna dilakukan, oleh karenanya kepada peneliti lain yang berminat meneliti topik yang sama untuk meneliti bagian-bagian yang tidak sempat diteliti; selanjutnya untuk adanya penguatan-penguatan, diharapkan bagi peneliti lain untuk melakukan penelitian lanjutan guna verifikasi data hasil penelitian. 


\section{Daftar Rujukan}

Arikunto, Suharsimi; Suhardjono; Supardi. 2006. Penelitian Tindakan Kelas. Jakarta: PT Bumi Aksara.

Badan Standar Nasional Pendidikan. 2007. Peraturan Menteri Pendidikan Nasional Republik Indonesia Nomor 41 Tahun 2007. Jakarta: BSNP.

Dalvi. 2006. Upaya Meningkatkan Keaktifan Belajar Siswa dalam pembelajaran Agama dengan Menggunakan Metode Pembelajaran Aktif Tipe Quiz Team. Jurnal Guru. Jurnal Guru Vol. 3, No. 1, Juli 2006.

Darwanti. 2017. Efektivitas Metode Quiz Team dan Murder terhadap Aktivitas Belajar dan Kemampuan Pemecahan Masalah dalam Pembelajaran IPS pada Kelas VIII SMP Laboratorium Percontohan UPI. Jurnal Pendidikan Ilmu Sosial, Volume 26, Nomor 1 Hal. 18-25. Tersedia Pada:, https://ejournal.upi.edu/index.php/jpis/article/download/6926/pdf.

Departemen Pendidikan Nasional. 2003. Kurikulum 2004. Jakarta: Depdiknas.

Depdiknas. 2002. Metode Pembelajaran Team Quiz. Jakarta: Dirjen Pendidikan Dasar dan Menengah.

Depdiknas. 2011. Membimbing Guru dalam Penelitian Tindakan Kelas. Jakarta: Pusat Pengembangan Tenaga Kependidikan Badan Pengembangan Sumber Daya Manusia Pendidikan Penjaminan Mutu Pendidik.

Direktorat Tenaga Kependidikan, Direktorat Jendral Peningkatan Mutu Pendidik dan Tenaga Kependidikan. 2008. Metode dan Teknik Supervisi. Jakarta: Depdiknas.

Hermanto, Bambang, Eny Winaryati. 2018. Penerapan Model Discovery Learning dengan Variasi Team Quiz sebagai Upaya Peningkatan Aktivitas dan Prestasi Belajar Kimia pada Materi Struktur Atom. Seminar Nasional Edusainstek FMIPA UNIMUS Hal. 526-538. Tersedia Pada: https://jurnal.unimus.ac.id/index.php/psn12012010/article/view/4175/3874.

Marcella, Adelia, Imanuel Adhitya Wulanata, Tanti Listiani. 2018. Penerapan Team Quiz untuk Meningkatkan Kemampuan Kerja Sama Antar Siswa Kelas VIII-B pada Mata Pelajaran Matematika [The Implementation of A Team Quiz to Improve The Cooperation Skills Among Grade 8B Students in Mathematics]. JOHME: Journal of Holistic Mathematics Education Hal. 124-134. Tersdia Pada: https://ojs.uph.edu/index.php/JOHME/article/view/799.

Modern Educators and Lexicographers. 1939. Webster's New American Detionary. New York: 140 Broadway, Books, Inc.

Munirah. 2015. Sistem Pendidikan di Indonesia: antara keinginan dan realita. Auladuna, Vol. 2 No. 2 Hal. 233-245. Tersedia Pada: http://journal.uin-alauddin.ac.id/index.php/auladuna/article/view/879.

Peraturan Menteri Pendidikan Nasional No. 41 Tahun 2007 Tanggal 23 November 2007. Jakarta: Depdiknas.

Sahertian, Piet A \& Aleida Sahertian. 1992. Supervisi Pendidikan dalam Rangka Program Inservice Education. Jakarta: Rineka Cipta.

Saputra, I Made Rai, dkk. 2017. Pengaruh Model Pembelajaran Quiz Team Berbasis Permainan Kamus Mini terhadap Hasil Belajar IPS Siswa Kelas V SD Gugus IV Abiansemal Tahun Pelajaran 2016/2017. EJurnal Mimbar PGSD Undiksha Volume 5 Nomor 2. ttp://dx.doi.org/10.23887/jjpgsd.v5i2.10778

Soedomo, M. 2001. Landasan Pendidikan. Malang: Penyelenggara Pendidikan Pascasarjana Proyek Peningkatan Perguruan Tinggi.

Srijayanti, Ni Putu Sukma, dkk. 2014. Model Pembelajaran Team Quiz Berbantuan Media Gambar Berpengaruh Terhadap Hasil Belajar IPS Siswa Kelas V. E-Jurnal Mimbar PGSD Undiksha Volume 2 Nomor 1. http://dx.doi.org/10.23887/jjpgsd.v2i1.3230

Sukidin, Basrowi, Suranto. 2002. Menajemen Penelitian Tindakan Kelas. Penerbti: Insan Cendekia ISBN: 9799048334.

Supardi, 2005. Pengembangan Profesi dan Ruang Lingkup Karya Ilmiah. Jakarta: Depdiknas.

Surya, Mohammad. 2004. Psikologi Pembelajaran dan Pengajaran. Bandung: Pustaka Bani Quraisy.

Tim Redaksi Fokusmedia. 2006. Himpunan Peraturan Perundang-undangan. Bandung: Fokus Media. 
Fadilah, R. U. (2019). Penerapan Model Pembelajaran Quiz Team Untuk Meningkatkan Hasil Belajar Ekonomi Peserta Didik Kelas Xi Ips 2 Sman 8 Kediri Di Semester Ganjil Tahun Pelajaran 2018/2019. Journal of Sharia Economics, 1(2), 146-164. https://doi.org/https://doi.org/10.35896/jse.v1i2.74

Marcella, A., Wulanata, I. A., \& Listiani, T. (2018). Penerapan Team Quiz Untuk Meningkatkan Kemampuan Kerja Sama Antar Siswa Kelas Viii-B Pada Mata Pelajaran Matematika [the Implementation of a Team Quiz To Improve Cooperation Skills Among Grade 8B Students in Mathematics]. JOHME: Journal of Holistic Mathematics Education, 1(2), 124. https://doi.org/10.19166/johme.v1i2.799

Sabil, H., \& Winarni, S. (2013). Meningkatkan Hasil Belajarmatematika Siswa Padamateri Persamaan Kuadrat Dengan Metode Belajar Aktif Tipe Quiz Team Di Kelas Ix Smpn 24 Kota Jambi. Edumatica, 03(02). https://doi.org/https://doi.org/10.22437/edumatica.v3i02.1581 